\title{
ANALISA PERBANDINGAN KEPUASAN PENUMPANG ANGKUTAN UMUM DAN ANGKUTAN UMUM BERBASIS APLIKASI ( Studi Kasus : Masyarakat Kota Cianjur )
}

\author{
Devi Setiawan \\ Jurusan Teknik Sipl Fakultas Teknik \\ Universitas Suryakancana Cianjur \\ Email : deviFT@unsur.ac.id
}

\begin{abstract}
Abstrak
Penelitian ini adalah untuk mengidentifikasi kualitas pelayanan angkutan umum konvensional yang berupa angkutan kota dan angkutan umum berbasis aplikasi dengan sampel dari aplikasi Grabcar dikota Cianjur variabel yang digunakan yaitu keamanan, keselamatan, kenyamanan, ketrerjangkaun, kesetaraan, dan keteraturan.

Metode yang digunakan dalam penelitian ini yaitu dengan metode diagram kartesius matriks importance-performance yang terbagi dalam 4 kuadaran Hasil analisis meliputi empat saran berbeda berdasarkan ukuran tingkat kepentingan (importance) dan kualitas / kondisi ruang (performance), yang selanjutnya dapat dipergunakan sebagai dasar untuk menetapkan rekomendasi selanjutnya.

Penerapan standar pelayanan minimal angkutan umum untuk angkutan kota belum cukup memuaskan responden penumpang angkutan umum dengan rata-rata skor untuk kinerja adalah 3,41 dan untuk rata-rata skor untuk tingkat harapan 2,72 dengan rata-rata tingkat kesusaian 80\%. Dengan atribut yang penting bagi responden penumpang angkutan kota dikota Cianjur yang pelaksanaan dilapangan jauh dari rasa kepuasan responden, variabel tersebut adalah variabel kinerja mesin dan variabel kebersihan interior angkutan yang perlu ditingkatkan lagi segi pelayanannya

Penerapan standar pelayanan minimal angkutan umum online untuk angkutan online grabcar cukup memuaskan responden penumpang angkutan umum dengan rata-rata skor untuk kinerja adalah 3,89 dan untuk rata-rata skor untuk tingkat harapan 3,86 dengan rata-rata tingkat kesusaian $100 \%$. atribut yang penting bagi responden penumpang angkutan online grabcar dikota Cianjur yang pelaksanaan dilapangan jauh dari rasa kepuasan responden, variabel tersebut adalah tingkat tampilan fasilitas dan peralatan angkutan, tingkat kebersihan eksterior angkutan, dan tingkat kebersihan interior angkutan.
\end{abstract}

Kata kunci : pelayanan angkutan umum, ipa, konvensional, online

\section{PENDAHULUAN}

Kabupaten Cianjur merupakan salah satu Kabupaten/kota yang cukup pesat perkembangannya terutama di pusat kota Cianjur dengan berbagai aktifitas seperti perdagangan dan jasa, pendidikan, perkantoran dan permukiman. Dengan kondisi yang ada ternyata sangat mempengaruhi pemilihan moda untuk melakukan aktifitas pergerakan aktivitasnya. Dalam ini penduduk kota cianjur lebih memilih moda secara Aplikasi/online dibandingkan dengan moda angkutan umum setelah survey pendahuluan dengan wawancara.
Pemilihan moda transportasi menurut sebagian ahli perencanaan transportasi, dianggap sebagai tahapan terpenting dalam perencanaan transportasi.Karena pada tahap pilihan moda ini untuk menentukan karakteristik apa saja yang akan kita nikmati saat kita memilih moda angkutan tersebut.

Transportasi konvensional nampaknya masih kurang memenuhi kenyamanan pengguna sehingga mereka lebih memilih menggunakan kendaraan pribadi atau bagi mereka yang menengah menggunakan transportasi online. Transportasi online, yang sebenarnya tidak berbeda jauh dengan transportasi 
konvensional, tetapi lebih nyaman dan harga juga lebih terjangkau. Keberadaan transportasi online ini sedikit menyingkirkan transportasi konvensional, karena di era teknologi yang mulai pesat, kita dapat memesan transportasi atau kendaraan yang lebih aman, nyaman dan lebih terjangkau.

Semua kemudahan dan kenyamanan yang diberikan oleh transportasi online, menimbulkan kegaduhan antara jasa angkutan konvesional dan online. Para supir konvensional mengeluhkan ketidakadilan dan jasa angkutan online harus dihapuskan karena penghasilan mereka berkurang setelah ada jasa angkutan yang disediakan oleh penyedia aplikasi online. Para supir angkutan umum membayar pajak dan juga belum ada peraturan resmi untuk penyedia aplikasi transportasi, mereka meresa lahan mata pencaharian mereka diambil, dan mereka merasa berat karena mereka sebagai angkutan umum yang terdaftar membayar pajak pada negara. Adanya perbedaan tariff juga membuat mereka merasa keberatan, karena tariff online lebih murah dibanding dengan konvensional yang lebih mahal.

Maksud penelitian ini adalah mengidentifikasi kualitas pelayanan angkutan umum konvensional ( angkutan kota ) dan angkutan umum berbasis aplikasi ( Grabcar) dikota Cianjur. Berdasarkan standar pelayanan angkutan umum, dan juga untuk mengetahui standar pelayanan minimal angkutan umum konvensional dan angkutan angkutan berbasis aplikasi yang perlu ditingkatkan dan dipertahankan tingkat pelayanannya dikota Cianjur

\section{METODOLOGI}

Pada penelitian ini akan dilakukan pengumpulan data primer melalui instrument kuesioner. Instrument kuesioner ini dibagikan pada responden yang mewakili satu populasi. Penelitian ini ditujukan pada pengguna angkutan umum konvensional ( Angkot ) dan yang berbasis aplikasi ( Grabcar ) di Kota Cianjur. Metode penelitian yang digunakan dalam penyusunan tesis ini adalah metode survey. Metode survey digunakan untuk mendapatkan data dari tempat tertentu yang alamiah (bukan buatan), dimana peneliti melakukan perlakuan dalam pengumpulan data, misalnya dengan kuesioner, test atau dengan wawancara.

Tingkat kepuasan pengguna jasa angkutan merupakan tanggapan ( opini ) dari responden yang dirasakan terhadap pelayanan kepuasan, setelah meraka membandingkan kualitas jasa yang diterima terhadap harapan pelayanan jasa angkutan tersebut. Bentuk pertanyaan yang diajukan terhadap responden disiapkan dalam bentuk dua sisi yaitu dari aspek kualitas pelayanan serta tanggapan pengguna jasa dan masing-masing variabel/dimensi mengandung beberapa indikator seperti berikut ini

Tabel 2.1. Instrumen Tingkat Pelayanan Angkutan Umum

\begin{tabular}{|c|c|c|}
\hline No & Dimensi & Atribut \\
\hline 1 & Keamanan & $\begin{array}{ll}\text { P1. } & \begin{array}{l}\text { Keselamatan } \\
\text { dalam perjalanan }\end{array} \\
\text { P2. } & \begin{array}{l}\text { Keamanan dari } \\
\text { tindakan kriminal } \\
\text { ketika dalam } \\
\text { perjalanan }\end{array} \\
\end{array}$ \\
\hline 2 & Kru & 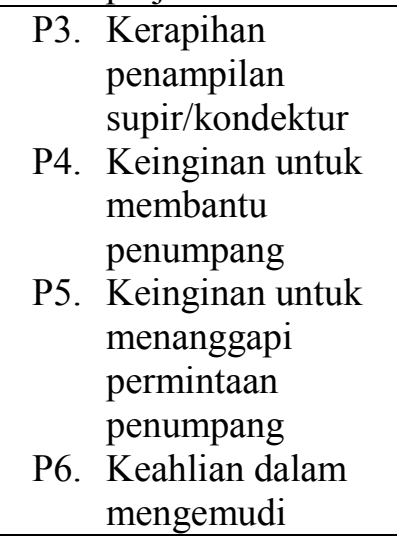 \\
\hline 3 & Kenyamanan & $\begin{aligned} & \text { P7. } \text { Kenyamanan } \\
& \text { tempat duduk } \\
& \text { P8. } \\
& \text { Tingkat } \\
& \text { kesesakan dalam } \\
& \text { angkutan } \\
& \text { P9. } \\
& \text { Kenyamanan } \\
& \text { suhu udara dalam } \\
& \text { angkutan }\end{aligned}$ \\
\hline 4 & $\begin{array}{l}\text { Kinerja \& } \\
\text { Kehandalan }\end{array}$ & $\begin{array}{l}\text { P10. Kinerja mesin } \\
\text { P11. Waktu tunggu } \\
\text { P12. Waktu perjalanan } \\
\text { P13. Ketaatan terhadap } \\
\text { peraturan }\end{array}$ \\
\hline 5 & $\begin{array}{c}\text { Kondisi } \\
\text { Kendaraan } \\
\& \\
\text { Fasilitasnya }\end{array}$ & 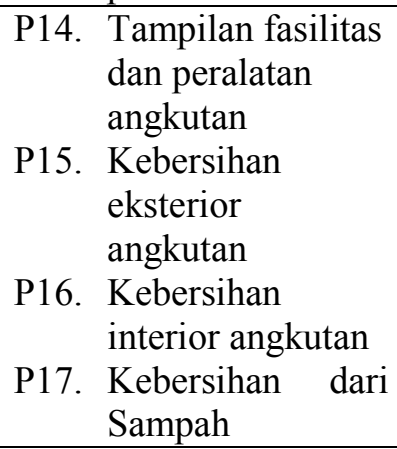 \\
\hline
\end{tabular}




\subsection{Penentuan Jumlah Sampel}

Salah satu metode yang digunakan untuk menentukan jumlah sampel adalah menggunakan metode dari Isaac dan Michael (Sugiyono, 2006). Dengan memberikan kemudahan penentuan jumlah sampel berdasarkan tingkat kesalahan $1 \%, 5 \%$ dan $10 \%$. Dengan tabel ini, peneliti dapat secara langsung menentukan besaran sampel berdasarkan jumlah populasi dan tingkat kesalahan yang dikehendaki dengan rumus sebagai berikut:

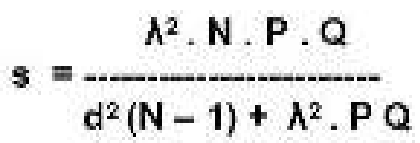

dimana :

$\mathrm{s}=$ Jumlah sampel

$\mathrm{N}=$ Jumlah populasi

$\lambda 2=$ Chi Kuadrat, dengan $\mathrm{dk}=1$, taraf kesalahan $1 \%, 5 \%$ dan $10 \%$

$\mathrm{d}=0,05$

$\mathrm{P}=\mathrm{Q}=0,5$

Dalam penelitian ini didasarkan jumlah penduduk di 4 kecamatan Kabupaten Cianjur dengan tingkat kesalahan sebesar 5\% dan tingkat kepercayaan 95\%, pada sampel yang diambil :

Tabel 2.2. Jumlah Responden

\begin{tabular}{|c|l|c|c|}
\hline No & Kecamatan & $\begin{array}{c}\text { Jumlah } \\
\text { Pendudu } \\
\mathrm{k}\end{array}$ & $\begin{array}{c}\text { Jumlah } \\
\text { Respond } \\
\text { en }\end{array}$ \\
\hline 1 & $\begin{array}{l}\text { Karang } \\
\text { tengah }\end{array}$ & 138,891 & 109 \\
\hline 2 & Cianjur kota & 163,828 & 110 \\
\hline 3 & Cipanas & 108,115 & 78 \\
\hline 4 & Cugenang & 103,378 & 78 \\
\hline \multicolumn{3}{|c|}{ Jumlah Responden } & $\mathbf{3 7 5}$ \\
\hline $\begin{array}{l}\text { Sumber : Badan Statistik } \\
\text { Cianjur Th.2015 }\end{array}$
\end{tabular}

Pendataan mengenai latar belakang responden dilakukan dalam penelitian ini sebagai faktor-faktor yang mempengaruhi penilaian responden, yaitu usia responden, Pendidikan terakhir, tujuan dari perjalanan, tingkat keseringan

\subsection{Uji Validitas dan Realibilitas}

Sebelum melakukan penelitian, terlebih dahulu dilakukan uji kuesioner untuk menguji validitas dan realibilitas, instrumen yang digunakan dalam penelitian ini adalah kuesioner. Uji validitas dan realibilitas dilakukan dengan bantuan perangkat lunak SPSS.

\section{Uji Validitas}

Validitas menggambarkan sejauh mana suatu alat pengukur (kuesioner) itu mengukur apa yang ingin diukur (Singarimbun, 1994 : 124). Untuk mengetahui validitas instrument, penelitian ini menggunakan korelasi product moment dengan angka kasar yang dikemukakan oleh Pearson sebagai berikut (Suharsimi, 2002 : 146)

\section{Uji Realibilitas}

Realibilitas adalah indeks yang menunjukan sejauh mana suatu alat pengukur dapat dipercaya atau dapat diandalkan dan hasil pengukuran relatif konstan apabila pengukuran pada gejala yang sama diulangi dua kali atau lebih (singarimbun, 1994 :140). Keandalan yang rendah akan mencerminkan ketidak konsistenan responden dalam menjawab pertanyaan. Suatu pernyataan dikatakan realibel dan dapat mengukur variabel dimaksud jika nilai koofesien relibilitasnya lebih dari atau sama dengan 0,7 (Kapan dan Saccuzzo, $1993: 126$ ).

\subsection{Mencari Tingkat Kesesuaian}

Dalam metode ini pengukuran tingkat kesesuaian untuk mengetahui seberapa besar pelanggan/konsumen merasa puas terhadap kinerja angkutan umum, dan seberapa pihak penyedia jasa memahami apa yang diinginkan pelanggan terhadap jasa yang mereka berikan.

Kriteria penilaian tingkat kesesuaian pelanggan/penumpang :

a) Tingkat kesesuaian penumpang $>100 \%$, berarti kualitas layanan yang diberikan telah melebihi apa yang dianggap penting oleh pelanggan artinya Pelayanan sangat memuaskan

b) Tingkat kesesuaian penumpang $=100 \%$, berarti kualitas layanan yang diberikan memenuhi apa yang dianggap penting oleh pelanggan artinya Pelayanan telah memuaskan

c) Tingkat kesesuaian $<100 \%$ berarti kualitas layanan yang diberikan kurang/tidak memenuhi apa yang dianggap penting oleh 
pelanggan artinya Pelayanan belum memuaskan.

Analisis kesesuaian dilakukan dengan menghitung tingkat kesesuaian terlebih dahulu, lalu menghitung nilai rata-rata harapan dan persepsi untuk masing-masing pernyataan (faktor). Faktor-faktor tersebut diperingkatkan kemudian dikelompokkan menjadi empat bagian kuadran dalam diagram kartesius

\section{4.. Diagram kartesius}

Analisis tingkat kepentingan dan kepuasan konsumen dapat menghasilkan suatu diagram kartesius yang dapat menunjukkan letak faktor-faktor atau unsur-unsur yang dianggap mempengaruhi kepuasan konsumen, dimana dalam diagram kartesius tersebut faktor-faktor akan dijabarkan dalam empat kuadran.

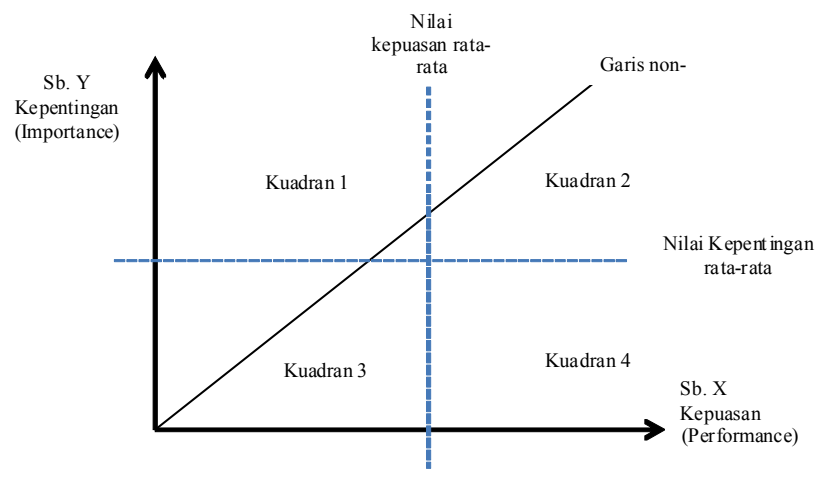

Gambar 2.1. Importance-Performance Grid Diagram Kartesius

Selanjutnya tingkat unsur-unsur tersebut akan dijabarkan dan dibagi menjadi empat bagian dalam diagram kartesius matriks importanceperformance sebagai berikut (Nia 2017) :

1. Kuadran 1 (Concentrate Here), merupakan wilayah yang memuat faktor-faktor yang dianggap penting oleh pengguna namun pada kenyataannya belum sesuai seperti yang diharapkan (kepuasan yang diperoleh masih sangat rendah).. Konsep strategi manajerial dalam kuadran ini berupa atrributes to improve, yaitu atribut-atribut yang harus ditingkatkan. Dalam angkutan umum ada beberapa variabel yang dianggap penting oleh penumpang

2. Kuadran 2 (Keep Up The Good Work), merupakan wilayah yang memuat faktorfaktor yang dianggap penting oleh pengguna dan sudah sesuai dengan yang dirasakan sehingga tingkat kepuasannya relatif lebih tinggi. Konsep strategi manajerial dalam kuadran ini berupa maintain performance, dimana performa atribut-atribut yang masuk dalam kuadran ini harus dipertahankan. penumpang angkutan umum, angible (wujud) dan assurance (jaminan dan kepastian)

3. Kuadran 3 (Low Priority), merupakan wilayah yang memuat faktor-faktor yang dianggap kurang penting oleh pengguna dan pada kenyataannya kinerjanya tidak terlalu memuaskan. Konsep strategi manajerial dalam kuadran ini berupa attributes to maintain, yaitu atribut bukan menjadi prioritas, melainkan dijadikan pendukung dalam sistem.

4. Kuadran 4 (Possible Overkill), merupakan wilayah yang memuat faktor-faktor yang dianggap kurang penting oleh pengguna dan tetapi layanan yang disediakan dirasakan terlalu berlebihan. Konsep strategi manajerial dalam kuadran ini berupa attributes to de-emphasize, contyaitu menekan kinerja atribut untuk meningkatkan efisiensi sumber daya.

\section{HASIL DAN PEMBAHASAN}

\subsection{Data Umum Responden}

Rekap Responden bisa dilihat pada tabel berikut

Tabel. 3.1. Usia Responden

\begin{tabular}{|c|c|c|}
\hline Umur & $\mathbf{F}$ & $\%$ \\
\hline 17-24 tahun & 189 & 50 \\
\hline 25-34 tahun & 126 & 34 \\
\hline 35-49 tahun & 60 & 16 \\
\hline Jumlah & 375 & 100 \\
\hline
\end{tabular}

Tabel. 3.2. Jenis Kelamin Responden

\begin{tabular}{|c|c|c|}
\hline jenis kelamin & $\mathbf{F}$ & $\%$ \\
\hline laki - laki & 233 & 62 \\
\hline Perempuan & 142 & 38 \\
\hline Jumlah & 375 & 100 \\
\hline
\end{tabular}

Tabel 3.3. Tingkat Pendidikan Responden

\begin{tabular}{|l|c|c|}
\hline Tingkat Pendidikan & F & \% \\
\hline SD & 21 & 6 \\
\hline SMP & 7 & 2 \\
\hline SMA & 127 & 34 \\
\hline Diplomat & 38 & 10 \\
\hline Sarjana & 123 & 33 \\
\hline
\end{tabular}




\begin{tabular}{|l|c|c|} 
Magister & 52 & 14 \\
\hline Doktor & 7 & 2 \\
\hline Jumlah & $\mathbf{3 7 5}$ & $\mathbf{1 0 0}$ \\
\hline \multicolumn{2}{|r|}{ Sumber $:$ Hasil pengolahan data , 2018}
\end{tabular}

Tabel 3.4. Tujuan Perjalanan Responden

\begin{tabular}{|c|c|c|}
\hline Tujuan Perjalanan & $\mathbf{F}$ & $\%$ \\
\hline ke Kantor & 49 & 13 \\
\hline ke Sekolah / Kampus & 189 & 50 \\
\hline Ke Pusat Perbelanjaan & 65 & 17 \\
\hline Mengunjungi teman / keluarga & 72 & 19 \\
\hline Jumlah & 375 & 100 \\
\hline
\end{tabular}

Tabel 3.5. Penggunaan Angkutan Umum Responden

\begin{tabular}{|c|c|c|}
\hline Penggunaan angkutan & $\mathbf{F}$ & $\%$ \\
\hline kurang dari 3 kali & 127 & 34 \\
\hline 3 - 6 kali & 83 & 22 \\
\hline 7 - 10 kali & 48 & 13 \\
\hline Lebih dari 10 kali & 117 & 31 \\
\hline Jumlah & 375 & 100 \\
\hline
\end{tabular}

\subsection{Hasil Validitas Dan Reabilitas Angkutan Kota Cianjur}

Tabel 3.6 Uji Validitas dan Reabilitas Kuisioner Angkutan Kota

\begin{tabular}{|c|c|c|c|c|c|c|c|}
\hline \multicolumn{4}{|c|}{ Kinerja } & \multicolumn{4}{|c|}{ Harapan } \\
\hline $\begin{array}{l}\text { Perta } \\
\text { nyaan }\end{array}$ & $\begin{array}{c}\mathbf{r} \\
\text { hitung } \\
\end{array}$ & $r$ tabel & $\begin{array}{c}\text { Kete } \\
\text { rangan }\end{array}$ & $\begin{array}{l}\text { Perta } \\
\text { nyaan }\end{array}$ & $\begin{array}{c}\mathbf{r} \\
\text { hitung }\end{array}$ & $r$ tabel & $\begin{array}{c}\text { Kete } \\
\text { rangan }\end{array}$ \\
\hline P 1 & 0.665 & 0,3 & Valid & P 1 & 0.823 & 0,3 & Valid \\
\hline P 2 & 0.759 & 0,3 & Valid & P 2 & 0.827 & 0,3 & Valid \\
\hline P 3 & 0.642 & 0,3 & Valid & P 3 & 0.809 & 0,3 & Valid \\
\hline P 4 & 0.524 & 0,3 & Valid & P 4 & 0.862 & 0,3 & Valid \\
\hline P 5 & 0.577 & 0,3 & Valid & P 5 & 0.867 & 0,3 & Valid \\
\hline P 6 & 0.713 & 0,3 & Valid & P 6 & 0.840 & 0,3 & Valid \\
\hline P 7 & 0.582 & 0,3 & Valid & P 7 & 0.879 & 0,3 & Valid \\
\hline P 8 & 0.502 & 0,3 & Valid & P 8 & 0.836 & 0,3 & Valid \\
\hline P 9 & 0.693 & 0,3 & Valid & P 9 & 0.848 & 0,3 & Valid \\
\hline P 10 & 0.656 & 0,3 & Valid & P 10 & 0.903 & 0,3 & Valid \\
\hline P 11 & 0.526 & 0,3 & Valid & P 11 & 0.852 & 0,3 & Valid \\
\hline P 12 & 0.556 & 0,3 & Valid & P 12 & 0.885 & 0,3 & Valid \\
\hline P 13 & 0.676 & 0,3 & Valid & P 13 & 0.920 & 0,3 & Valid \\
\hline P 14 & 0.621 & 0,3 & Valid & P 14 & 0.891 & 0,3 & Valid \\
\hline P 15 & 0.736 & 0,3 & Valid & P 15 & 0.897 & 0,3 & Valid \\
\hline P 16 & 0.649 & 0,3 & Valid & P 16 & 0.840 & 0,3 & Valid \\
\hline P 17 & 0.568 & 0,3 & Valid & P 17 & 0.846 & 0,3 & Valid \\
\hline
\end{tabular}


Pengujian reliabilitas untuk pengujian variabel pertanyaan kuisioner untuk angkutan kota cianjur diatas dengan menggunakan dengan bantuan Sofware SPSS didapatkan hasil Cronbach's Alpha untuk kinerja angkutan kota sebesar 0.773 dan harapan angkutan kota sebesar 0,758. Besarnya koefisien Cronbach's Alpha menunjukkan tingkat reliability yang sangat erat/realibel $>0.60$

\subsection{Hasil Validitas dan Reabiltas Grabcar}

Tabel 3.7. Uji Validitas dan Reabilitas Kuisioner Angkutan Grabcar

\begin{tabular}{|c|c|c|c|c|c|c|c|}
\hline \multicolumn{4}{|c|}{ Kinerja } & \multicolumn{4}{|c|}{ Harapan } \\
\hline $\begin{array}{l}\text { Perta } \\
\text { nyaan }\end{array}$ & $\begin{array}{c}\mathbf{r} \\
\text { hitung }\end{array}$ & $r$ tabel & $\begin{array}{c}\text { Kete } \\
\text { rangan }\end{array}$ & $\begin{array}{l}\text { Perta } \\
\text { nyaan }\end{array}$ & $\begin{array}{c}\mathbf{r} \\
\text { hitung }\end{array}$ & $r$ tabel & $\begin{array}{c}\text { Kete } \\
\text { rangan }\end{array}$ \\
\hline P 1 & 0.665 & 0,3 & Valid & P 1 & 0.823 & 0,3 & Valid \\
\hline P 2 & 0.759 & 0,3 & Valid & P 2 & 0.827 & 0,3 & Valid \\
\hline P 3 & 0.642 & 0,3 & Valid & P 3 & 0.809 & 0,3 & Valid \\
\hline P 4 & 0.524 & 0,3 & Valid & P 4 & 0.862 & 0,3 & Valid \\
\hline P 5 & 0.577 & 0,3 & Valid & P 5 & 0.867 & 0,3 & Valid \\
\hline P 6 & 0.713 & 0,3 & Valid & P 6 & 0.840 & 0,3 & Valid \\
\hline P 7 & 0.582 & 0,3 & Valid & P 7 & 0.879 & 0,3 & Valid \\
\hline P 8 & 0.502 & 0,3 & Valid & P 8 & 0.836 & 0,3 & Valid \\
\hline P 9 & 0.693 & 0,3 & Valid & P 9 & 0.848 & 0,3 & Valid \\
\hline P 10 & 0.656 & 0,3 & Valid & P 10 & 0.903 & 0,3 & Valid \\
\hline P 11 & 0.526 & 0,3 & Valid & P 11 & 0.852 & 0,3 & Valid \\
\hline P 12 & 0.556 & 0,3 & Valid & P 12 & 0.885 & 0,3 & Valid \\
\hline P 13 & 0.676 & 0,3 & Valid & P 13 & 0.920 & 0,3 & Valid \\
\hline P 14 & 0.621 & 0,3 & Valid & P 14 & 0.891 & 0,3 & Valid \\
\hline P 15 & 0.736 & 0,3 & Valid & P 15 & 0.897 & 0,3 & Valid \\
\hline P 16 & 0.649 & 0,3 & Valid & P 16 & 0.840 & 0,3 & Valid \\
\hline P 17 & 0.568 & 0,3 & Valid & P 17 & 0.846 & 0,3 & Valid \\
\hline
\end{tabular}

Sumber : Hasil pengolahan data dengan SPSS, 2018

Pengujian reliabilitas untuk pengujian variabel pertanyaan kuisioner untuk Grabcar cianjur diatas dengan menggunakan dengan bantuan Sofware SPSS didapatkan hasil Cronbach's Alpha untuk tingkat kinerja Grabcar sebesar 0.758 dan tingkat harapan Grabcar sebesar 0,770. Besarnya koefisien Cronbach's Alpha menunjukkan tingkat reliability yang sangat erat $/$ realebel $>0.60$ 
3.4. Rata Rata Nilai Tingkat Kesesuaian Kepuasan Penumpang

Tabel 3.7. Nilai Rata-rata Tingkat Kesesuain Kinerja dan harapan Angkutan Kota

\begin{tabular}{|c|c|c|c|c|}
\hline $\begin{array}{l}\mathbf{N} \\
\mathbf{0} \\
\cdot\end{array}$ & $\begin{array}{l}\text { VARIABEL } \\
\text { PELAYAN } \\
\text { AN }\end{array}$ & $\begin{array}{l}\text { Rata - } \\
\text { rata } \\
\text { Kiner } \\
\text { ja }\end{array}$ & $\begin{array}{l}\text { Rata } \\
\text {-rata } \\
\text { Hara } \\
\text { pan }\end{array}$ & $\begin{array}{l}\text { Ting } \\
\text { kat } \\
\text { kesus } \\
\text { ain } \\
(\%)\end{array}$ \\
\hline \multicolumn{5}{|c|}{ Keamanan } \\
\hline 1 & $\begin{array}{l}\text { Tingkat } \\
\text { keselamatan } \\
\text { dalam } \\
\text { perjalanan }\end{array}$ & 3.54 & 2.88 & 81 \\
\hline 2 & $\begin{array}{l}\text { Tingkat } \\
\text { Keamanan } \\
\text { dari tindakan } \\
\text { kriminal } \\
\text { ketika dalam } \\
\text { perjalanan }\end{array}$ & 3.50 & 2.68 & 76 \\
\hline \multicolumn{5}{|c|}{$\begin{array}{l}\text { Kru Angkutan } \\
\text { umum }\end{array}$} \\
\hline 3 & $\begin{array}{l}\text { Tingkat } \\
\text { Kerapihan } \\
\text { penampilan } \\
\text { supir/kondek } \\
\text { tur }\end{array}$ & 3.37 & 2.67 & 79 \\
\hline 4 & $\begin{array}{l}\text { Tingkat } \\
\text { Keinginan } \\
\text { untuk } \\
\text { membantu } \\
\text { penumpang }\end{array}$ & 3.52 & 2.95 & 84 \\
\hline 5 & $\begin{array}{l}\text { Tingkat } \\
\text { Keinginan } \\
\text { untuk } \\
\text { menanggapi } \\
\text { permintaan } \\
\text { penumpang }\end{array}$ & 3.61 & 2.87 & 80 \\
\hline 6 & $\begin{array}{l}\text { Tingkat } \\
\text { Keahlian } \\
\text { dalam } \\
\text { mengemudi }\end{array}$ & 3.54 & 3.17 & 89 \\
\hline \multicolumn{5}{|c|}{ Kenyamanan } \\
\hline 7 & $\begin{array}{l}\text { Tingkat } \\
\text { Kenyamanan } \\
\text { tempat } \\
\text { duduk }\end{array}$ & 3.42 & 2.80 & 82 \\
\hline 8 & $\begin{array}{l}\text { Tingkat } \\
\text { kesesakan } \\
\text { dalam } \\
\text { angkutan }\end{array}$ & 3.20 & 2.32 & 73 \\
\hline 9 & $\begin{array}{l}\text { Tingkat } \\
\text { Kenyamanan }\end{array}$ & 3.35 & 2.53 & 76 \\
\hline
\end{tabular}

\begin{tabular}{|c|c|c|c|c|}
\hline & $\begin{array}{l}\text { suhu udara } \\
\text { dalam } \\
\text { angkutan }\end{array}$ & & & \\
\hline \multicolumn{5}{|c|}{$\begin{array}{ll}\text { Kinerja } & \& \\
\text { Kehandalan } & \\
\end{array}$} \\
\hline $\begin{array}{l}1 \\
0\end{array}$ & $\begin{array}{l}\text { Tingkat } \\
\text { Kinerja } \\
\text { mesin }\end{array}$ & 3.37 & 3.10 & 92 \\
\hline $\begin{array}{l}1 \\
1\end{array}$ & $\begin{array}{l}\text { Tingkat } \\
\text { Waktu } \\
\text { tunggu } \\
\text { Kendaraan }\end{array}$ & 3.53 & 2.64 & 75 \\
\hline $\begin{array}{l}1 \\
2\end{array}$ & $\begin{array}{l}\text { Tingkat } \\
\text { Waktu/lama } \\
\text { perjalanan }\end{array}$ & 3.39 & 2.35 & 69 \\
\hline $\begin{array}{l}1 \\
3\end{array}$ & $\begin{array}{l}\text { Tingkat } \\
\text { Ketaatan } \\
\text { terhadap } \\
\text { peraturan } \\
\text { Lalu Lintas } \\
\end{array}$ & 3.43 & 2.87 & 84 \\
\hline \multicolumn{5}{|c|}{$\begin{array}{ll}\text { Kondisi } & \\
\text { Kendaraan } & \& \\
\text { Fasilitasnya } & \\
\end{array}$} \\
\hline $\begin{array}{l}1 \\
4\end{array}$ & $\begin{array}{l}\text { Tingkat } \\
\text { Tampilan } \\
\text { fasilitas dan } \\
\text { peralatan } \\
\text { angkutan }\end{array}$ & 3.32 & 2.56 & 77 \\
\hline $\begin{array}{l}1 \\
5\end{array}$ & $\begin{array}{l}\text { Tingkat } \\
\text { Kebersihan } \\
\text { eksterior } \\
\text { angkutan }\end{array}$ & 3.39 & 2.56 & 76 \\
\hline $\begin{array}{l}1 \\
6\end{array}$ & $\begin{array}{l}\text { Tingkat } \\
\text { Kebersihan } \\
\text { interior } \\
\text { angkutan }\end{array}$ & 3.24 & 2.76 & 85 \\
\hline $\begin{array}{l}1 \\
7\end{array}$ & $\begin{array}{l}\text { Tingkat } \\
\text { Kebersihan } \\
\text { dari Sampah }\end{array}$ & 3.27 & 2.54 & 78 \\
\hline \multicolumn{2}{|c|}{ Rata - rata } & 3.41 & 2.72 & 80 \\
\hline
\end{tabular}

Dari urutan prioritas di atas dapat di lihat bahwa faktor yang paling tidak sesuai antara Kinerja dan Harapan adalah faktor Tingkat Waktu/lama perjalanan sebesar 69 $\%<100 \%$ yang artinya pelayanan belum cukup memuaskan. Sementara faktor yang tingkat kesesuaiannya mendekati antara Kinerja dan Harapan adalah Tingkat Kinerja mesin sebesar $92 \%<100 \%$ pelayanan belum cukup memuaskan. Secara rata-rata kepuasan penumpang angkutan kota cianjur menurut responden pelayanannya belum cukup memuasakan. 
Tabel 3.8. Nilai Rata-rata Tingkat Kesesuain Kinerja dan harapan Grabcar

\begin{tabular}{|c|c|c|c|c|}
\hline $\begin{array}{l}\mathbf{N} \\
\mathbf{0}\end{array}$ & $\begin{array}{c}\text { VARIABEL } \\
\text { PELAYANA } \\
\mathbf{N}\end{array}$ & $\begin{array}{l}\text { Rata - } \\
\text { rata } \\
\text { Kinerja }\end{array}$ & $\begin{array}{c}\text { Rata } \\
\text {-rata } \\
\text { Hara } \\
\text { pan }\end{array}$ & $\begin{array}{c}\text { Ting } \\
\text { kat } \\
\text { kesu } \\
\text { sain } \\
(\% \\
) \\
\end{array}$ \\
\hline \multicolumn{5}{|c|}{ Keamanan } \\
\hline 1 & $\begin{array}{l}\text { Tingkat } \\
\text { keselamatan } \\
\text { dalam } \\
\text { perjalanan }\end{array}$ & 3.79 & 3.70 & 98 \\
\hline 2 & $\begin{array}{l}\text { Tingkat } \\
\text { Keamanan } \\
\text { dari tindakan } \\
\text { kriminal } \\
\text { ketika dalam } \\
\text { perjalanan }\end{array}$ & 3.91 & 3.43 & 88 \\
\hline \multicolumn{5}{|c|}{$\begin{array}{l}\text { Kru Angkutan } \\
\text { umum }\end{array}$} \\
\hline 3 & $\begin{array}{l}\text { Tingkat } \\
\text { Kerapihan } \\
\text { penampilan } \\
\text { supir/kondekt } \\
\text { ur }\end{array}$ & 3.90 & 3.79 & 97 \\
\hline 4 & $\begin{array}{l}\text { Tingkat } \\
\text { Keinginan } \\
\text { untuk } \\
\text { membantu } \\
\text { penumpang }\end{array}$ & 3.85 & 3.82 & 99 \\
\hline 5 & $\begin{array}{l}\text { Tingkat } \\
\text { Keinginan } \\
\text { untuk } \\
\text { menanggapi } \\
\text { permintaan } \\
\text { penumpang }\end{array}$ & 4.05 & 3.91 & 97 \\
\hline 6 & $\begin{array}{l}\text { Tingkat } \\
\text { Keahlian } \\
\text { dalam } \\
\text { mengemudi }\end{array}$ & 4.01 & 3.83 & 96 \\
\hline \multicolumn{5}{|c|}{ Kenyamanan } \\
\hline 7 & $\begin{array}{l}\text { Tingkat } \\
\text { Kenyamanan } \\
\text { tempat duduk }\end{array}$ & 3.90 & 4.06 & 104 \\
\hline 8 & $\begin{array}{l}\text { Tingkat } \\
\text { kesesakan } \\
\text { dalam } \\
\text { angkutan }\end{array}$ & 4.11 & 4.08 & 99 \\
\hline 9 & $\begin{array}{l}\text { Tingkat } \\
\text { Kenyamanan } \\
\text { suhu udara } \\
\text { dalam } \\
\text { angkutan }\end{array}$ & 4.00 & 3.91 & 98 \\
\hline & erja \& & & & \\
\hline
\end{tabular}

\begin{tabular}{|c|c|c|c|c|}
\hline \multicolumn{2}{|c|}{ Kehandalan } & \multirow[b]{2}{*}{4.13} & \multirow[b]{2}{*}{3.91} & \multirow[b]{2}{*}{95} \\
\hline $\begin{array}{l}1 \\
0\end{array}$ & $\begin{array}{l}\text { Tingkat } \\
\text { Kinerja mesin }\end{array}$ & & & \\
\hline $\begin{array}{l}1 \\
1\end{array}$ & $\begin{array}{l}\text { Tingkat } \\
\text { Waktu tunggu } \\
\text { Kendaraan }\end{array}$ & 3.84 & 3.81 & 99 \\
\hline $\begin{array}{l}1 \\
2\end{array}$ & $\begin{array}{l}\text { Tingkat } \\
\text { Waktu/lama } \\
\text { perjalanan }\end{array}$ & 3.90 & 3.90 & 100 \\
\hline $\begin{array}{l}1 \\
3\end{array}$ & $\begin{array}{l}\text { Tingkat } \\
\text { Ketaatan } \\
\text { terhadap } \\
\text { peraturan Lalu } \\
\text { Lintas }\end{array}$ & 3.81 & 3.75 & 99 \\
\hline \multicolumn{2}{|c|}{$\begin{array}{l}\text { Kondisi } \\
\text { Kendaraan \& } \\
\text { Fasilitasnya }\end{array}$} & & & \\
\hline $\begin{array}{l}1 \\
4\end{array}$ & $\begin{array}{l}\text { Tingkat } \\
\text { Tampilan } \\
\text { fasilitas dan } \\
\text { peralatan } \\
\text { angkutan }\end{array}$ & 3.75 & 3.99 & 106 \\
\hline $\begin{array}{l}1 \\
5\end{array}$ & $\begin{array}{l}\text { Tingkat } \\
\text { Kebersihan } \\
\text { eksterior } \\
\text { angkutan }\end{array}$ & 3.76 & 3.90 & 104 \\
\hline $\begin{array}{l}1 \\
6\end{array}$ & $\begin{array}{l}\text { Tingkat } \\
\text { Kebersihan } \\
\text { interior } \\
\text { angkutan }\end{array}$ & 3.71 & 4.05 & 109 \\
\hline $\begin{array}{l}1 \\
7\end{array}$ & $\begin{array}{l}\text { Tingkat } \\
\text { Kebersihan } \\
\text { dari Sampah }\end{array}$ & 3.77 & 3.79 & 101 \\
\hline \multicolumn{2}{|c|}{ Rata-rata } & 3.89 & 3.86 & 100 \\
\hline
\end{tabular}

Dari urutan prioritas di atas dapat di lihat bahwa faktor yang paling tidak sesuai antara Kinerja dan Harapan adalah faktor Tingkat Keamanan dari tindakan kriminal ketika dalam perjalanan sebesar $88 \%<100$ $\%$ yang artinya pelayanan belum cukup memuaskan Sementara faktor yang tingkat kesesuaiannya mendekati antara Kinerja dan Harapan adalah Tingkat Kebersihan interior angkutan sebesar $109 \%>100 \%$ yang artinya pelayanan memuaskan. Secara rata-rata kepuasan responden terhadap pelayanan Grabcar sangat memuaskan.

\subsection{Matriks Importance-Performance Diagram Tingkat Kinerja dan Harapan Angkutan Kota}




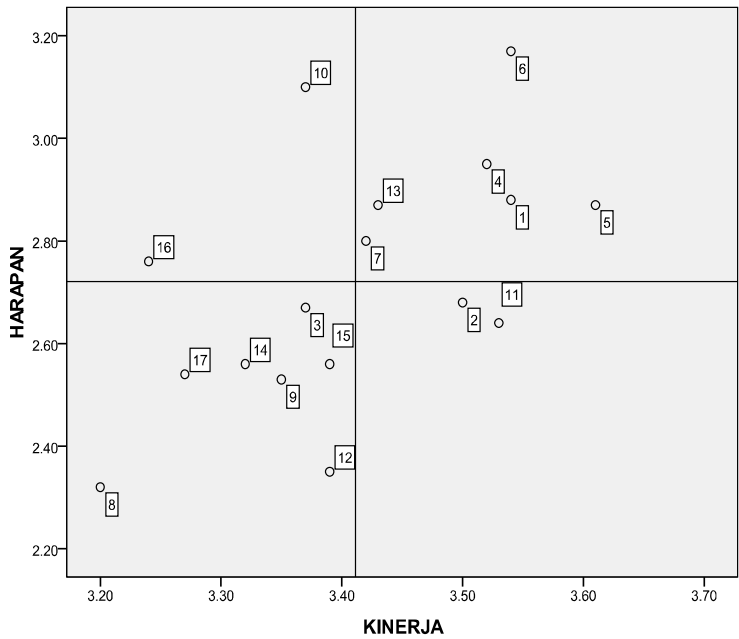

Gambar 3.1. Diagram Importance Performance Angkutan kota

Sumber : Hasil pengolahan data, 2018

\section{Hasil Analisis Pada Kuadran I (Concentrate Here)}

Kuadran 1 (Concentrate Here), merupakan wilayah yang memuat faktor-faktor yang dianggap penting oleh pengguna namun pada kenyataannya belum sesuai seperti yang diharapkan (kepuasan yang diperoleh masih sangat rendah)

\begin{tabular}{|c|c|c|c|}
\hline & $\begin{array}{lrr}\text { Tabel 3.9.. } & T \\
\text { Pelayanan } & \text { An }\end{array}$ & $\begin{array}{l}\text { el } V \\
\text { utan }\end{array}$ & $\begin{array}{l}\text { iabel } \\
\text { kota }\end{array}$ \\
\hline No. & $\begin{array}{l}\text { VARIABEL } \\
\text { PELAYANAN }\end{array}$ & $\begin{array}{l}\text { Rata } \\
\text { - rata } \\
\text { Kiner } \\
\text { ja }\end{array}$ & $\begin{array}{l}\text { Rata } \\
\text {-rata } \\
\text { Hara } \\
\text { pan }\end{array}$ \\
\hline $\begin{array}{l}\mathrm{P} \\
10\end{array}$ & $\begin{array}{l}\text { Tingkat Kinerja } \\
\text { mesin }\end{array}$ & 3.37 & 3.10 \\
\hline $\begin{array}{l}P \\
16\end{array}$ & $\begin{array}{l}\text { Tingkat Kebersihan } \\
\text { interior angkutan }\end{array}$ & 3.24 & 2.76 \\
\hline
\end{tabular}

2. Hasil Analisis Pada Kuadran II (Keep Up The Good Work)

Kuadran II, merupakan wilayah yang memuat faktor-faktor yang dianggap penting oleh pengguna dan sudah sesuai dengan yang dirasakan sehingga tingkat kepuasannya relatif lebih tinggi. Konsep strategi manajerial dalam kuadran ini berupa maintain performance, dimana performa atribut-atribut yang masuk dalam kuadran ini harus dipertahankan.
Tabel 3.10. Tabel Variabel Pelayanan Angkutan kota Kuadran II

\begin{tabular}{|l|l|l|l|}
\hline No. & $\begin{array}{l}\text { VARIABEL } \\
\text { PELAYANAN }\end{array}$ & $\begin{array}{l}\text { Rata } \\
\text { - rata } \\
\text { Kine } \\
\text { rja }\end{array}$ & $\begin{array}{l}\text { Rata- } \\
\text { rata } \\
\text { Hara } \\
\text { pan }\end{array}$ \\
\hline P 1 & $\begin{array}{l}\text { Tingkat keselamatan } \\
\text { dalam perjalanan }\end{array}$ & 3.54 & 2.88 \\
\hline P 4 & $\begin{array}{l}\text { Tingkat Keinginan } \\
\text { untuk membantu } \\
\text { penumpang }\end{array}$ & 3.52 & 2.95 \\
\hline P 5 & $\begin{array}{l}\text { Tingkat Keinginan } \\
\text { untuk menanggapi } \\
\text { permintaan penumpang }\end{array}$ & 3.61 & 2.87 \\
\hline P 6 & $\begin{array}{l}\text { Tingkat Keahlian dalam } \\
\text { mengemudi }\end{array}$ & 3.54 & 3.17 \\
\hline P 7 & $\begin{array}{l}\text { Tingkat Kenyamanan } \\
\text { tempat duduk }\end{array}$ & 3.42 & 2.80 \\
\hline P & $\begin{array}{l}\text { Tingkat Ketaatan } \\
\text { terhadap peraturan Lalu } \\
\text {-Lintas }\end{array}$ & 3.43 & 2.87 \\
\hline
\end{tabular}

\section{Hasil Analisis Pada Kuadran III} (Low Priority)

Kuadran 3 merupakan wilayah yang memuat faktor-faktor yang dianggap kurang penting oleh pengguna dan pada kenyataannya kinerjanya tidak terlalu memuaskan. Konsep strategi manajerial dalam kuadran ini berupa attributes to maintain.

Tabel 3.11. Tabel Variabel Pelayanan Angkutan kota Kuadran III

\begin{tabular}{|l|l|l|l|}
\hline No. & $\begin{array}{l}\text { VARIABEL } \\
\text { PELAYANAN }\end{array}$ & $\begin{array}{l}\text { Rata - } \\
\text { rata } \\
\text { Kinerja }\end{array}$ & $\begin{array}{l}\text { Rata- } \\
\text { rata } \\
\text { Harapan }\end{array}$ \\
\hline P 3 & $\begin{array}{l}\text { Tingkat Kerapihan } \\
\text { penampilan } \\
\text { supir/kondektur }\end{array}$ & 3.37 & 2.67 \\
\hline P 8 & $\begin{array}{l}\text { Tingkat kesesakan } \\
\text { dalam angkutan }\end{array}$ & 3.20 & 2.32 \\
\hline P 9 & $\begin{array}{l}\text { Tingkat Kenyamanan } \\
\text { suhu udara dalam } \\
\text { angkutan }\end{array}$ & 3.35 & 2.53 \\
\hline P 12 & $\begin{array}{l}\text { Tingkat Waktu/lama } \\
\text { perjalanan }\end{array}$ & 3.39 & 2.35 \\
\hline P 14 & $\begin{array}{l}\text { Tingkat Tampilan } \\
\text { fasilitas dan peralatan } \\
\text { angkutan }\end{array}$ & 3.32 & 2.56 \\
\hline P 15 & $\begin{array}{l}\text { Tingkat Kebersihan } \\
\text { eksterior angkutan }\end{array}$ & 3.39 & 2.56 \\
\hline P 17 & $\begin{array}{l}\text { Tingkat Kebersihan dari } \\
\text { Sampah }\end{array}$ & 3.27 & 2.54 \\
\hline
\end{tabular}


4. Hasil Analisis Pada Kuadran IV (Possible Overkill)

Kuadran 4 merupakan wilayah yang memuat faktor-faktor yang dianggap kurang penting oleh penumpang dan tetapi layanan yang disediakan dirasakan terlalu berlebihan. Adapun atribut yang masuk dalam pelayanan angkutan kota yang masuk dalam atribut kuadran 4 adalah :

\begin{tabular}{|l|l|l|l|}
\multicolumn{5}{c}{$\begin{array}{l}\text { Tabel 3.12. } \\
\text { Pelayanan } \\
\text { Angkutan kota Kuadran IV }\end{array}$} \\
\hline No. & $\begin{array}{l}\text { VARIABEL } \\
\text { PELAYANAN }\end{array}$ & $\begin{array}{l}\text { Rata - } \\
\text { rata } \\
\text { Kinerja }\end{array}$ & $\begin{array}{l}\text { Rata- } \\
\text { rata } \\
\text { Harapan }\end{array}$ \\
\hline P 2 & $\begin{array}{l}\text { Tingkat } \\
\text { Keamanan dari } \\
\text { tindakan kan } \\
\text { kriminal ketika } \\
\text { dalam perjalanan }\end{array}$ & 3.50 & 2.68 \\
\hline P 11 & $\begin{array}{l}\text { Tingkat Waktu } \\
\text { tunggu Kendaraan }\end{array}$ & 3.53 & 2.64 \\
\hline
\end{tabular}

3.6. Matriks Importance Performance Diagram Tingkat Kinerja dan Harapan Grabcar.

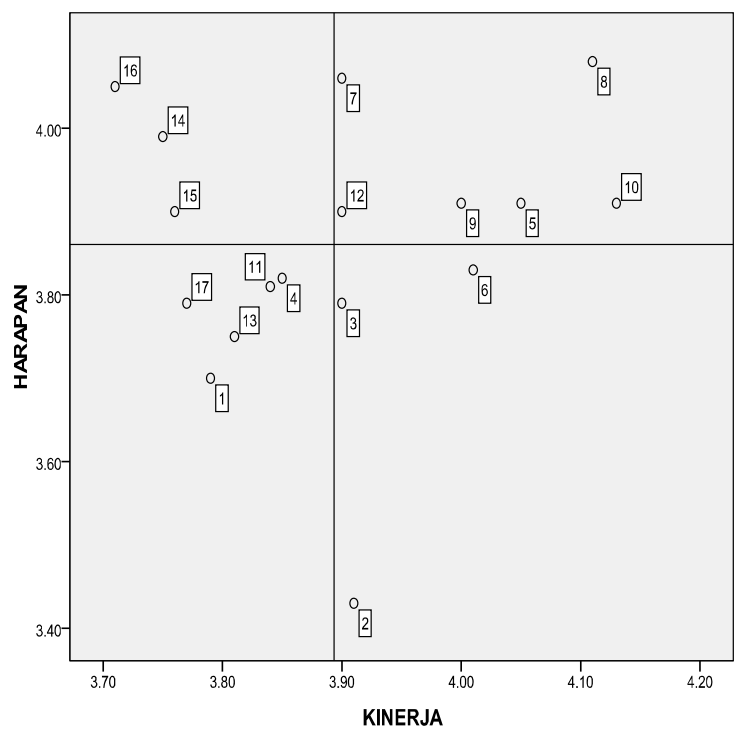

Gambar 4.2. Diagram Importance Performance Grabcar Sumber : Hasil pengolahan data, 2018

\section{Hasil Analisis Pada Kuadran I (Concentrate Here)}

Kuadran 1 (Concentrate Here), merupakan wilayah yang memuat faktor-faktor yang dianggap penting oleh penumpang namun pada kenyataannya belum sesuai seperti yang diharapkan (kepuasan yang diperoleh masih sangat rendah).

Tabel 3.13. Nilai Rata-rata Kinerja dan harapan Grabcar

\begin{tabular}{|l|l|l|l|}
\hline No. & $\begin{array}{l}\text { VARIABEL } \\
\text { PELAYANAN }\end{array}$ & $\begin{array}{l}\text { Rata - } \\
\text { rata } \\
\text { Kinerja }\end{array}$ & $\begin{array}{l}\text { Rata- } \\
\text { rata } \\
\text { Harapan }\end{array}$ \\
\hline P 14 & $\begin{array}{l}\text { Tingkat Tampilan } \\
\text { fasilitas dan peralatan } \\
\text { angkutan }\end{array}$ & 3.75 & 3.99 \\
\hline P 15 & $\begin{array}{l}\text { Tingkat Kebersihan } \\
\text { eksterior angkutan }\end{array}$ & 3.76 & 3.90 \\
\hline P 16 & $\begin{array}{l}\text { Tingkat Kebersihan } \\
\text { interior angkutan }\end{array}$ & 3.71 & 4.05 \\
\hline
\end{tabular}

\section{Hasil Analisis Pada Kuadran II} (Keep Up The Good Work)

Kuadran II, merupakan wilayah yang memuat faktor-faktor yang dianggap penting oleh penumpang dan sudah sesuai dengan yang dirasakan sehingga tingkat kepuasannya relatif lebih tinggi. Konsep strategi manajerial dalam kuadran ini berupa maintain performance.

Tabel 3.14. Nilai Rata-rata Kinerja dan harapan Grabcar

\begin{tabular}{|l|l|l|l|}
\hline No. & \multicolumn{1}{|c|}{$\begin{array}{c}\text { VARIABEL } \\
\text { PELAYANAN }\end{array}$} & $\begin{array}{l}\text { Rata - } \\
\text { rata } \\
\text { Kinerja }\end{array}$ & $\begin{array}{l}\text { Rata- } \\
\text { rata } \\
\text { Harapan }\end{array}$ \\
\hline P 5 & $\begin{array}{l}\text { Tingkat Keinginan } \\
\text { untuk menanggapi } \\
\text { permintaan } \\
\text { penumpang }\end{array}$ & 4.05 & 3.91 \\
\hline P 7 & $\begin{array}{l}\text { Tingkat Kenyamanan } \\
\text { tempat duduk }\end{array}$ & 3.90 & 4.06 \\
\hline P 8 & $\begin{array}{l}\text { Tingkat kesesakan } \\
\text { dalam angkutan }\end{array}$ & 4.11 & 4.08 \\
\hline P 9 & $\begin{array}{l}\text { Tingkat Kenyamanan } \\
\text { suhu udara dalam } \\
\text { angkutan }\end{array}$ & 4.00 & 3.91 \\
\hline P 10 & Tingkat Kinerja mesin & 4.13 & 3.91 \\
\hline P 12 & $\begin{array}{l}\text { Tingkat Waktu/lama } \\
\text { perjalanan }\end{array}$ & 3.90 & 3.90 \\
\hline
\end{tabular}

\section{Hasil Analisis Pada Kuadran III (Low Priority) \\ Kuadran 3 merupakan wilayah yang} memuat faktor-faktor yang dianggap kurang penting oleh penumpang dan pada kenyataannya kinerjanya tidak terlalu memuaskan. Konsep strategi manajerial dalam kuadran ini berupa attributes to maintai. 
Tabel 3.15. Nilai Rata-rata Kinerja dan harapan Grabcar

\begin{tabular}{|l|l|c|c|}
\hline No. & $\begin{array}{c}\text { VARIABEL } \\
\text { PELAYANAN }\end{array}$ & $\begin{array}{c}\text { Rata - } \\
\text { rata } \\
\text { Kinerja }\end{array}$ & $\begin{array}{c}\text { Rata- } \\
\text { rata } \\
\text { Harapan }\end{array}$ \\
\hline P 1 & $\begin{array}{l}\text { Tingkat } \\
\text { keselamatan } \\
\text { dalam perjalanan }\end{array}$ & 3.79 & 3.70 \\
\hline P 4 & $\begin{array}{l}\text { Tingkat } \\
\text { Keinginan untuk } \\
\text { membantu } \\
\text { penumpang }\end{array}$ & 3.85 & 3.82 \\
\hline P 11 & $\begin{array}{l}\text { Tingkat Waktu } \\
\text { tunggu Kendaraan }\end{array}$ & 3.84 & 3.81 \\
\hline P 13 & $\begin{array}{l}\text { Tingkat Ketaatan } \\
\text { terhadap } \\
\text { peraturan Lalu } \\
\text { Lintas }\end{array}$ & 3.81 & 3.75 \\
\hline P 17 & $\begin{array}{l}\text { Tingkat } \\
\text { Kebersihan dari } \\
\text { Sampah }\end{array}$ & 3.77 & 3.79 \\
\hline
\end{tabular}

\section{Hasil Analisis Pada Kuadran IV (Possible Overkill)}

Kuadran 4 merupakan wilayah yang memuat faktor-faktor yang dianggap kurang penting oleh penumpang dan tetapi layanan yang disediakan dirasakan terlalu berlebihan.

Tabel 3.16. Nilai Rata-rata Kinerja dan harapan Grabcar

\begin{tabular}{|l|l|l|l|}
\hline No. & \multicolumn{1}{|c|}{$\begin{array}{c}\text { VARIABEL } \\
\text { PELAYANAN }\end{array}$} & $\begin{array}{l}\text { Rata - } \\
\text { rata } \\
\text { Kinerja }\end{array}$ & $\begin{array}{l}\text { Rata- } \\
\text { rata } \\
\text { Harapan }\end{array}$ \\
\hline P 2 & $\begin{array}{l}\text { Tingkat Keamanan } \\
\text { dari tindakan } \\
\text { kriminal ketika } \\
\text { dalam perjalanan }\end{array}$ & 3.91 & 3.43 \\
\hline P 3 & $\begin{array}{l}\text { Tingkat Kerapihan } \\
\text { penampilan } \\
\text { supir/kondektur }\end{array}$ & 3.90 & 3.79 \\
\hline P 6 & $\begin{array}{l}\text { Tingkat Keahlian } \\
\text { dalam mengemudi }\end{array}$ & 4.01 & 3.83 \\
\hline
\end{tabular}

\section{KESIMPULAN DAN SARAN}

\section{A. KESIMPULAN}

Hasil penelitian tentang Analisa Perbandingan Kepuasan Penumpang Angkutan Umum Dan Angkutan Umum Berbasis Aplikasi (Study Kasus : Masyarakat Kota Cianjur) dengan menggunakan variabelvariabel standart pelayanan angkutan umum berupa keamanan., kenyamanan, kru angkutan, kinerja dan keandalan dan kondisi kendaraan dan fasilitasnya. Dengan menggunakan metode Importance Performance Analysis ( IPA) adalah sebagai berikut :

1. Kepuasan responden penumpang angkutan konvensional (angkot) terhadap pelayanan angkutan umum :

a) Variabel yang berada pada kuadaran 1 dimana variabel ini merupakan variabel yang perlu ditingkatkan dari variabel standart pelayanan angkutan umum yang dianggap penting namun pada kenyataan dilapangan pelaksanaannya belum memuaskan responden angkutan kota Cianjur yaitu : variabel tingkat kinerja mesin dan variabel tingkat kebersihan interior.

b) Variabel yang berada pada kuadran 2 dimana variabel ini merupakan variabel yang perlu dipertahankan dan ditingkatkan, karena dianggap penting oleh responden dengan implentasi pelayanan dilapangan sudah dilakukan dengan baik, dengan variabel yaitu : Tingkat keselamatan dalam perjalanan, Tingkat Keinginan untuk membantu penumpang, Tingkat Keinginan untuk menanggapi permintaan penumpang, Tingkat Keahlian dalam mengemudi, Tingkat Kenyamanan tempat duduk dan Tingkat Ketaatan terhadap peraturan Lalu -Lintas.

c) Variabel yang berada pada kuadran 3 dan 4 dimana variabel ini merupakan variabel yang dianggap kurang penting bagi para responden penumpang angkutan kota, karena dianggap hanya sebagai pelengkap dalam pelayanan angkutan kota dikota Cianjur dengan variabel yaitu : kuadaran 3 : Tingkat Kerapihan penampilan supir/kondektur, Tingkat kesesakan dalam angkutan, Tingkat Kenyamanan suhu udara dalam angkutan, Tingkat Waktu/lama perjalanan, Tingkat Tampilan fasilitas dan peralatan angkutan, Tingkat Kebersihan eksterior angkutan, Tingkat Kebersihan dari Sampah, kuadaran 4 : Tingkat Keamanan dari tindakan kriminal ketika dalam perjalanan, dan Tingkat Waktu tunggu Kendaraan.

2. Kepuasan responden penumpang angkutan online (Grabcar) terhadap pelayanan angkutan umum :

a) Variabel yang berada pada kuadaran 1 dimana variabel ini merupakan variabel yang perlu ditingkatkan dari 
variabel standart pelayanan angkutan umum yang dianggap penting namun pada kenyataan dilapangan pelaksanaannya belum memuaskan responden angkutan online grabcar Cianjur yaitu : Tingkat Tampilan fasilitas dan peralatan angkutan, Tingkat Kebersihan eksterior angkutan, dan Tingkat Kebersihan interior angkutan.

b) Variabel yang berada pada kuadran 2 dimana variabel ini merupakan variabel yang perlu dipertahankan dan ditingkatkan, karena dianggap penting oleh responden dengan implentasi pelayanan dilapangan sudah dilakukan dengan baik, dengan variabel yaitu : Tingkat Keinginan untuk menanggapi permintaan penumpang, Tingkat Kenyamanan tempat duduk, Tingkat kesesakan dalam angkutan, Tingkat Kenyamanan suhu udara dalam angkutan, Tingkat Kinerja mesin, dan Tingkat Waktu/lama perjalanan

c) Variabel yang berada pada kuadran 3 dan 4 dimana variabel ini merupakan variabel yang dianggap kurang penting bagi para responden penumpang angkutan online grabcar , karena dianggap hanya sebagai pelengkap dalam pelayanan angkutan online grabcar dikota Cianjur dengan variabel yaitu : kuadran 3 : Tingkat keselamatan dalam perjalanan, Tingkat Keinginan untuk membantu penumpang, Tingkat Waktu tunggu Kendaraan, Tingkat Ketaatan terhadap peraturan Lalu Lintas, dan Tingkat Kebersihan dari Sampah, kuadran 4 : Tingkat Keamanan dari tindakan kriminal ketika dalam perjalanan, Tingkat Kerapihan penampilan supir/kondektur, dan Tingkat Keahlian dalam mengemudi.

3. Penerapan standar pelayanan minimal angkutan umum untuk angkutan kota belum cukup memuaskan responden penumpang angkutan umum dengan ratarata skor untuk kinerja adalah 3,41 dan untuk rata-rata skor untuk tingkat harapan 2,72 dengan rata-rata tingkat kesusaian $80 \%$. Dengan atribut yang penting bagi responden penumpang angkutan kota dikota Cianjur yang pelaksanaan dilapangan jauh dari rasa kepuasan responden, variabel tersebut adalah variabel kinerja mesin dan variabel kebersihan interior angkutan yang perlu ditingkatkan lagi segi pelayanannya

4. Penerapan standar pelayanan minimal angkutan umum online untuk angkutan online grabcar cukup memuaskan responden penumpang angkutan umum dengan rata-rata skor untuk kinerja adalah 3,89 dan untuk rata-rata skor untuk tingkat harapan 3,86 dengan rata-rata tingkat kesusaian $100 \%$. atribut yang penting bagi responden penumpang angkutan online grabcar dikota Cianjur yang pelaksanaan dilapangan jauh dari rasa kepuasan responden, variabel tersebut adalah Tingkat Tampilan fasilitas dan peralatan angkutan, Tingkat Kebersihan eksterior angkutan, dan Tingkat Kebersihan interior angkutan.

\section{B. SARAN}

1. Hasil penelitian ini merupakan hasil respon para penumpang angkutan umum yang hanya dsekitar kota Cianjur bukan secra keseluruhan kota Cianjur, maka hasil penelitian ini tidak mewakili daerahdaerah yang lain.sehingga perlu penelitian yang serupa di daerah lain dalam kepuasan pelayanan angkutan umum pengguna angkutan umum konvensional dan angkutan yang berbasis aplikasi.

2. Penelitian lebih lanjut dapat dilakukan terhadap variabel yang memang kurang memuaskan pengguna angkutan konvensional dan angkutan berbasis aplikasi secra mendalam dan terperinci.

3. Untuk para penyedia angkutan umum angkot dikota Cianjur agar lebih memperhatikan dan konsen terhadap peningkatan standar pelayanan angkutan umum yang telah ditentukan dalam SPM angkutan umum supaya bisa bersaing dengan angkutan umum berbasis aplikasi. Begitu juga dengan penyedia angkutan umum berbasis aplikasi agar memperhatikan variabel-variabel yang kurang memuaskan responden agar ada peningkatan kepuasan responden yang sesuai dengan Permenhub No 108/2017.

\section{DAFTAR PUSTAKA}

Morlok, Edward K, Introduction to Transportation Engenering and Planning, (diterjemahkan oleh Johan Kalanaputra Hainim, Pengantar Teknik dan Perencanaan Transportasi, Erlangga, Jakarta, 1995). 
Tamin, Ofyar Z, Perencanaan dan Pemodelan Transportasi, Penerbit ITB, Bandung, 1997.

Sugiyono, (2006), Statistik Untuk Penelitian, Cetakan Kesembilan, CV AlfaBeta, Bandung.

Singarimbun, M., 1989, Metode Penelitian Survey, , Jakarta : LP3S

Idris, Zilhardi, (2009). Kajian "Tingkat Kepuasan” Pengguna Angkutan Umum Di Diy, Dinamika teknik Sipil, Surakarta.

Juanita,Tito Pinandita, ( 20154) Kajian Kinerja Pelayanan Angkutan Umum Dalam Kota Di Purwokerto, Purwokerto.

Medi Yarmen1, I Gede Mahatma Yuda Bakti2, Kualitas Pelayanan Angkutan Kota (Angkot) Di Jawa Barat : Perspektif Siswa, Pusat Penelitian Sistem Mutu dan Teknologi Pengujian - LIPI, Tamgerang

Lustriana, Ir. Hera Widyastuti, MT Analisa Kepuasan Penumpang Angkutan Kota Terhadap Sistem Pelayanan Angkutan Kota Yang Tidak Mengikuti Trayek (Studi Kasus: Kota Palu)

Peraturan Menteri Perhubungan Nomor Pm 29 Tahun 2015 tentang Standar Pelayanan Minimal Angkutan Orang dengan Kendaraan Bermotor Umum dalam Trayek.

Peraturan Menteri Perhubungan RI Nomor PM 108 Tahun 2017 tentang Penyelenggaraan Angkutan Orang dengan Kendaran Bermotor Umum Tidak Dalam Trayek http://dephub.go.id/post/read/11pokok-materi-dalam-revisi-pm-32tahun-2016 diakses pada 20 agustus 2017 jam 10.00 wib

Badan Statistic Nasional ,Jumlah Penduduk Kota Cianjur Sensus Penduduk 2010 - Kabupaten Cianjur http://sp2010.bps.go.id/index.php/si te?id $=320$ 3000000\&wilayah $=$ Cianjur Sensus Penduduk 2010 - Kabupaten Cianjur, diakses pada 20 agustus 2017 Pkl. 10.18 wib

Data Dinas Perhubungan Kota Cianjur, 2017

Dinas perhubungan, 2017'mengenal dan memahami PM 108 Tahun 2017 “ http://dephub.go.id/post/read/meng enal-dan-memahami-pm-108tahun- diakses tanggal 23 september 2017
Nida azizah, 2015, "pengertian jasa transportasi

https://www.scribd.com/document/ 327242053/Pengertian-Jasa-

Transportasi-Online diambil tanggal 23 september 2017

Wikipedia, 2017, "Angkutan Kota" https://id.wikipedia.org/wiki/Angku tan kota diakses tanggal 23 september 2017

Yuk mampir kesini, 2016, "Transportasi online di Indonesia" http://yukmampirkesini.blogspot.c o.id/2016/05/transportasi-onlinedi- indonesia.html diambil tanggal 23 september 2017

JDIH | Kementerian Perhubungan, "Produk Hukum"

http://jdih.dephub.go.id/index.php/p roduk hukum/view/VUUwZ01qZ2 dWRUZJV1U0Z01qQXhOUT09

diakses tanggal 23 september 2017

Hukum online, 2016, "Angkutan Umum Yang Layak Dan Aman" http://www.hukumonline.com/klinik/ detail/1t5874843eb71ec/standarangkutan-umum-yang-layak-danaman. dakses 12 maret 2018 